Article

\title{
Bivariate Assessment of Drought Return Periods and Frequency in Brazilian Northeast Using Joint Distribution by Copula Method
}

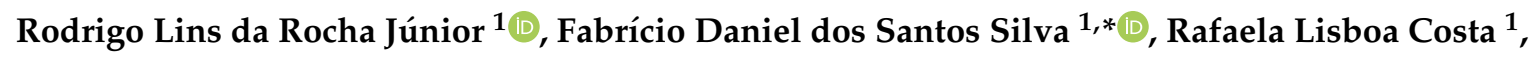 \\ Heliofábio Barros Gomes ${ }^{1}$, David Duarte Cavalcante Pinto ${ }^{1}$ and Dirceu Luis Herdies ${ }^{2}$ (D) \\ 1 Institute of Atmospheric Sciences, Federal University of Alagoas, Maceió, Alagoas 57072-900, Brazil; \\ rrodrigo.junior@hotmail.com (R.L.d.R.J.); rafaelalisboac@gmail.com (R.L.C.); heliofabio@icat.ufal.br (H.B.G.); \\ david.duarte@icat.ufal.br (D.D.C.P.) \\ 2 National Institute for Space Research, Cachoeira Paulista, São Paulo 12630-000, Brazil; \\ dirceu.herdies@inpe.br \\ * Correspondence: fabricio.santos@icat.ufal.br
}

Received: 20 March 2020; Accepted: 7 April 2020; Published: 10 April 2020

check for updates

\begin{abstract}
The Northeast region of Brazil (NRB) is the most populous semiarid area in the world and is extremely susceptible to droughts. The severity and duration of these droughts depend on several factors, and they do not necessarily follow the same behavior. The aim of this work is to evaluate the frequency of droughts in the NRB and calculate the return period of each drought event using the copula technique, which integrates the duration and severity of the drought in the NRB in a joint bivariate distribution. Monthly precipitation data from 96 meteorological stations spatially distributed in the NRB, ranging from 1961 to 2017, are used. The copula technique is applied to the Standardized Precipitation Index (SPI) on the three-month time scale, testing three families of Archimedean copula functions (Gumbel-Hougaard, Clayton and Frank) to reveal which model is best suited for the data. Averagely, the most frequent droughts observed in the NRB are concentrated in the northern sector of the region, with an observed duration varying from three and a half to five and a half months. However, the eastern NRB experiences the most severe droughts, lasting for 14 to 24 months. The probability distributions that perform better in modeling the series of severity and duration of droughts are exponential, normal and lognormal. The observed severity and duration values show that, for average values, the return period across the region is approximately 24 months. Still in this regard, the southernmost tip of the NRB stands out for having a return period of over 35 months. Regarding maximum observed values of severity and duration, the NRB eastern strip has the longest return period (>60 months), mainly in the southeastern portion where a return period above 90 months was observed. The northern NRB shows the shortest return period ( 45 months), indicating that it is the NRB sector with the highest frequency of intense droughts. These results provide useful information for drought risk management in the NRB.
\end{abstract}

Keywords: meteorological drought analysis; Standardized Precipitation Index (SPI); archimedean copulas; probability distributions

\section{Introduction}

Among adverse natural phenomena, drought is what most affects society by acting on large territorial extensions and lasting for long periods [1]. Overall, drought is characterized as a sufficiently long period of water deficiency to significantly impact edaphic, meteorological, hydrological and social aspects [2-8]. It is a phenomenon that imposes difficulties in the characterization of properties such as beginning, spatiotemporal extension and end, which makes its monitoring challenging [9]. 
Taking a local point of view, drought is a phenomenon that goes beyond the scope of climatology and becomes one of a socioeconomic nature as well [10]. The vulnerability of society depends on the interaction of various factors such as population, social life, politics, culture, technology, land use patterns, water use, economic development and diversity of grassroots economy [11].

There is a special interest in the study of drought in the NRB, as it is the most populous dry region in the world, with approximately 35 million inhabitants and a population density of about 34 inhabitants per square kilometer [12]. The phenomenon mainly affects the population that dwells in the semiarid region located in the most central portion of the NRB (Figure 1), creating scenarios that threaten water, food and energy security [13]. More recently, the drought of 2010-2016 has been the longest and most severe drought ever recorded in recent decades in the NRB, which has intensified the interest of the scientific community to study the subject [1,14].

Notable work has been done for the NRB, contributing to a solid understanding of drought-causing meteorological mechanisms [15-20], the social and political aspects involved in increasing the resilience of the population [21,22], as well as drought forecasting methods and their impacts on crops [8]. Other studies have evaluated the dynamics and changing patterns of drought in the NRB using indices that incorporate variables such as precipitation, temperature and evapotranspiration $[23,24]$ and other more specific statistical characteristics of drought [25].

All of these works provide useful information for drought risk management. However, there is no work for the NRB that has focused on calculating the drought return period based on probability theory. Probabilistic characterization of drought events is extremely important for the management and planning of water resource use [26]. Previous studies obtained the drought return period by univariate approaches, considering only drought duration series [27-29]. However, drought is a multivariate event and, therefore, univariate approaches tend to underestimate or overestimate the risk of drought [30-32].

To deal with droughts in a multivariate fashion, recent works have adopted joint distributions obtained from the copula technique. Ayantobo et al, [32] studied the return period of droughts in China's climate subgroups from the combined distribution of drought intensity, duration and severity series. Wang et al, [33] calculated the drought return period in Anhui Province (China) using bivariate joint distributions of drought duration and severity. Hui-Mean et al, [34] applied trivial distributions of severity, duration and intensity from copulas to analyse drought in Peninsular Malaysia.

Joint distributions obtained by copulas offer more advantages than other multivariate distributions, as they consider the probabilistic nature of each variable. A Gaussian multivariate distribution will always generate a normal and symmetric probability density function, for example. However, for hydroclimatic variables, the normality and symmetry of the data are not necessarily consistent with reality. Each region may have better fit in other distributions than Gaussian. Therefore, a technique that takes this into account is needed.

Considering this, the use of multivariate distributions-obtained by copulas that are calculated from the marginal distributions of each previously determined variable-arises. Moreover, the resulting probability density curve by copula will not be necessarily symmetric, offering an advantageous flexibility when it comes to studying and modeling complex relationships between variables.

Given the need for more information to help with drought risk management and water use planning in the NRB, the aim of this paper is to evaluate the frequency of drought in the NRB and to calculate the return period of drought events using the copula technique.

\section{Materials and Methods}

\subsection{Data and Area of Study}

The NRB is in an equatorial region between the parallels $1-21^{\circ} \mathrm{S}$ and the meridians $32-49^{\circ} \mathrm{W}$. NRB is approximately $1.6 \times 10^{6} \mathrm{~km}^{2}$ in area, which represents $18 \%$ of Brazil's territory (Figure 1 ). It encompasses nine states: Alagoas (AL), Piaui (PI), Maranhão (MA), Ceará (CE), Rio Grande do 
Norte (RN), Paraiba (PB), Pernambuco (PE), Sergipe (SE) and Bahia (BA). The characteristic vegetation of every coastal region is the Atlantic forest. The vegetation present in the central portion of the NRB (semiarid region) is the Caatinga. The transition region between the Caatinga and the Atlantic forest is called Agreste. Found in the extreme northwest of the region, in the state of MA, the typical vegetation of the Amazon forest predominates, whereas in the south of the state of MA and PI, and west of the state of BA, the Cerrado vegetation prevails [35].

The combination of diversified topography and the influence of varied meteorological systems cause great climate variability in the NRB, which has three large areas of nearly homogeneous rainfall variability: the Midwest, the North and the East [6,35-38]. The semiarid sector is characterized as the region where annual precipitation is less than $800 \mathrm{~mm}$. These areas are highlighted in Figure 1 (left panel).

The rainy period in the northern NRB is marked by the action of the Intertropical Convergence Zone (ITCZ) and Upper Tropospheric Cyclonic Vortexes (UTCV) during the austral summer and early autumn. The rainy season in the eastern sector and part of the central portion is marked by the action of UTCVs and the propagation of Easterly Wave Disturbances (EWDs) coming from the Atlantic Ocean during the months May-June-July (MJJ). UTCVs and Cold Fronts are the main rain generators in the southern sector of NRB during the austral summer, and EWDs in autumn/winter. The most central area of the NRB has its rainy season concentrated in the months of November-December-January, due to the South Atlantic Convergence Zone (SACZ) [39-46].
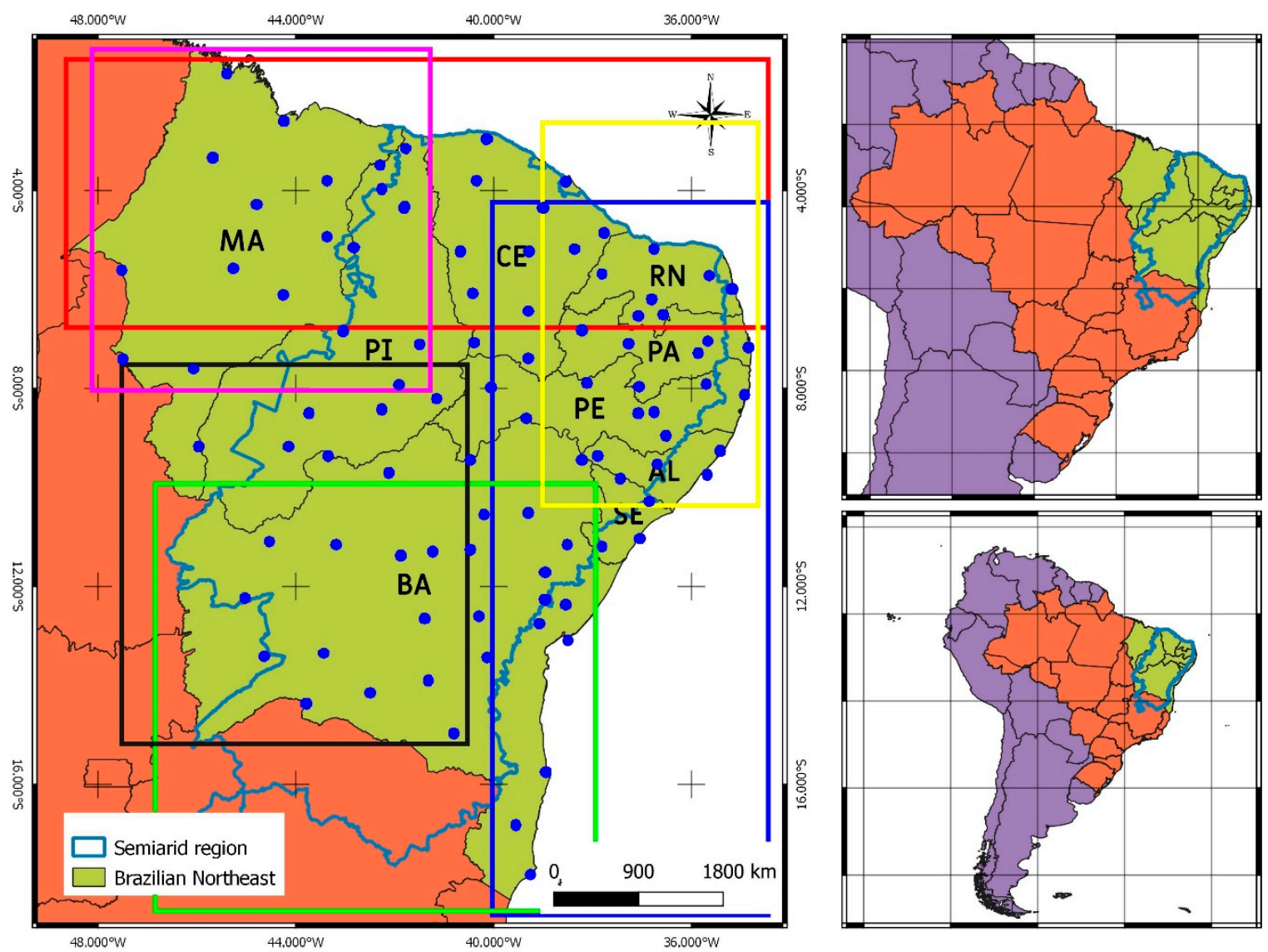

Figure 1. Map of the Brazilian Northeast with the delimitation of the semiarid region and its location in relation to Brazil and South America, respectively. Regarding the left panel, points representing INMET's weather stations are highlighted in blue. Concerning subregions, we highlight the north of NRB in red, the northwest in violet, the northeast in yellow, the east in blue, the south in green and the southwest in black. 
We used a monthly accumulated precipitation time series from 96 conventional surface weather stations of the Brazilian National Institute of Meteorology (INMET), comprising the period from 1961 to 2017. The location of surface weather stations can be seen merged in Figure 1 (left panel). INMET data are subjected to a rigorous quality control and homogenization, providing confidence in data processing [47-51].

The concern with the quality of the rainfall data of this research is due to the fact that such observed series of precipitation will be used for validation of products from simulations of weather and climate associated with the project "Development and Validation of Modeling of the Components of the Brazilian Earth System Model (BESM)". This project has, among other objectives, the one of understanding the formation of clouds and precipitation which constitute one of the great challenges for the modeling of the terrestrial system and, consequently, for the studies of climate simulations.

\subsection{Standardized Precipitation Index}

Several indexes were created to study drought quantitatively. The Palmer Drought Severity Index (PDSI) was the first index developed for this purpose. Furthermore, PDSI was a very important index for incorporating the effects of evapotranspiration [52,53]. Since PDSI parameters were fixed and originally calculated for the USA, the self-calibrated PDSI (Sc-PDSI) was later defined, which estimated its parameters based on inherent series characteristics [54]. However, PDSI and Sc-PDSI did not allow analysis at various time scales. To cope with the problem of temporal characterization of droughts, the SPI was developed [55]. The calculation of SPI is based on long-term precipitation series at different time scales, such as 1, 3, 6, or 12 months. Such a property of the index makes it suitable to classify droughts that range from the 1-month edaphic type all the way up to hydrological ones that may last for years. The main premise of SPI is to assume that precipitation is the key variable for drought classification. More recently, a new index was developed to combine the main characteristics of SPI and PDSI, the Standard Precipitation and Evapotranspiration Index [9]. However, due to the lack of directly measured Evapotranspiration (Etp) data and the scarce availability of the data necessary to at least estimate it, we opted for the use of the SPI in the present study. Since its inception, several works have used the SPI for spatial and temporal drought studies [56-58], and several environmental centers have made the SPI the official index for monitoring the phenomenon. Moreover, the SPI is the drought index recommended by the World Meteorological Organization [59].

Given its widespread use and extensive literature validating the SPI, we chose to use the three-month time scale index (SPI-3) to derive Duration (D) and Severity (S) series. The D and S series are obtained from the Run Theory drought frequency analysis method (Figure 2). Run Theory is a method for grouping independent drought events from time series based on the proximity of individual SPI observations with values below a threshold ( 0 in this work). Run Theory's premise is that very close negative SPI observations (even separated by small positive SPI intervals) represent observations from the same drought event. Added to the $\mathrm{D}$ and $\mathrm{S}$ of the events, the method provides the periods of non-occurrence of drought $(\mathrm{nD})$ and the length $(\mathrm{L})$ of periods of drought and non-drought. The mean values of $\mathrm{nD}$ and $\mathrm{L}$ will be used in Equation 3. Detailed information on SPI calculation is found in Mckee et al, [55]. Detailed information about the Run Theory can be found in Sun et al, [60].

\subsection{Bivariate Copula}

Copula functions are used to generate multivariate distributions from univariate marginal distributions. The theoretical basis of the technique was defined by Sklar. [61]. Subsequently, Genest et al., [62] established the definition of Archimedean copula functions, which often are used in hydrological variable analysis [32,63-65]. 


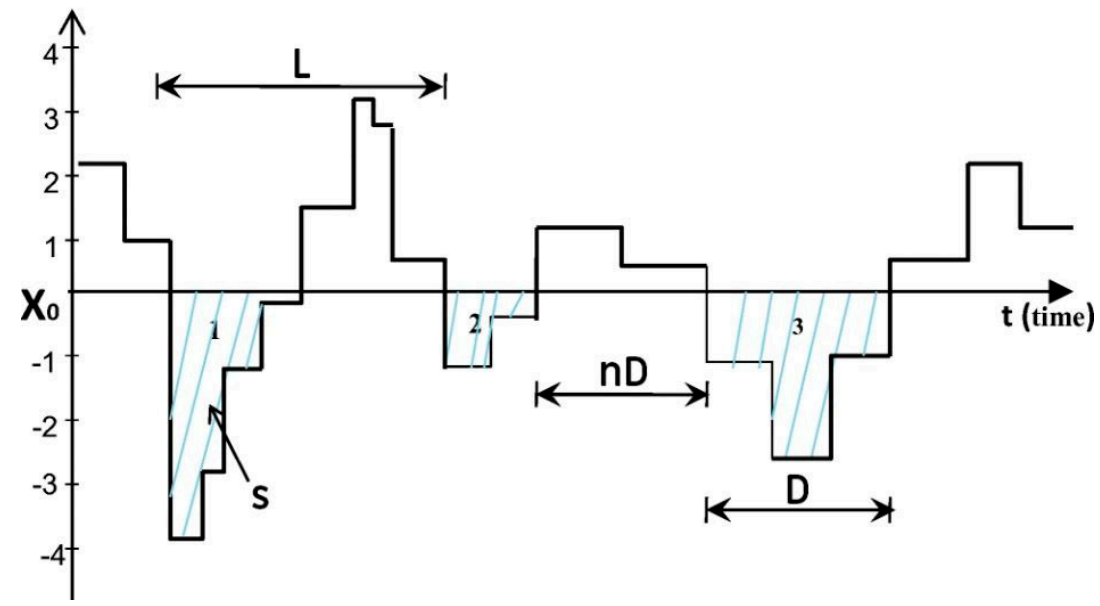

Figure 2. Calculation scheme of drought Severity (S), Duration (D), non-occurrence of drought (nD) and length (L) of drought and non-drought periods using the Run Theory method.

Copula functions are defined as multivariate distribution functions, $P\left(x_{1}, \ldots, x_{n}\right)$, with uniformly distributed variables on the interval $[0,1]$ :

$$
P\left(x_{1}, \ldots, x_{n}\right)=C\left[P\left(x_{1}\right), \ldots, P\left(x_{n}\right)\right]=C\left(u_{1}, \ldots, u_{n}\right)
$$

where $C$ is the Cumulative Distribution Function (CDF) of the copula, and $P\left(x_{i}\right)$ is the marginal distribution of $x_{i}$, being uniform on the interval [0,1], which also is denoted by $u_{i}$ The $P(\ldots)$ in the left-hand side is the joint probability distribution.

Among the several existing Archimedean copula families, these work-tested copula functions of three families are frequently used in drought analyses (Table 1) $[32,66,67]$. Given that the series of $S$ and D have a correlation (linear or nonlinear) to each other expressed by the Kendall correlation $(\tau)$, it is possible to estimate the parameter $\theta$ of the copula functions by the relationships shown in the third column of Table 1. We apply the Akaike Information Criterion (AIC) (Equation 2) to select, for each season, the copula that is best suited for modelling the properties of the drought [68]:

$$
A I C=2 k-2 \ln (\hat{L})
$$

where $k$ is the number of the estimated parameter in the model and $\hat{L}$ is the maximum value of the likelihood function for the model. The copula function that has the lowest AIC value is the most suitable copula for the surface weather station.

Table 1. Archimedean copulas: families of tested functions (left column), functions of each family (central column) and relationship equations between $\tau$ and $\theta$ (right column).

\begin{tabular}{ccc}
\hline Family & Bivariate Copula & Relationship between $\boldsymbol{\tau}$ and $\boldsymbol{\theta}$ \\
\hline Gumbel-Hougaard & $\exp \left\{-\left[\left(-\ln u_{1}\right)^{\theta}+\left(-\ln u_{2}\right)^{\theta}\right]^{\frac{1}{\theta}}\right\}$ & $\tau=1-\frac{1}{\theta}$ \\
Clayton & $\max \left(\left[u_{1}-\theta+u_{2}{ }^{-\theta}-1\right]^{\frac{-1}{\theta}}, 0\right)$ & $\tau=\frac{\theta}{\theta+2}$ \\
Frank & $-\frac{1}{\theta} \ln \left[1+\frac{\left(e^{-\theta u_{1}-1}\right)\left(e^{-\theta u_{2}-1}\right)}{\left(e^{-\theta}-1\right)}\right]$ & $\tau=1+\frac{4}{\theta}\left[\frac{1}{\theta} \int_{0}^{\theta} \frac{t}{e^{t}-1} d t-1\right]$ \\
\hline
\end{tabular}

\subsection{Marginal Distribuitions for Drought Severity and Duration}

A good performance in modeling the drought characteristics by joint distributions depends, fundamentally, on the appropriate choice of the marginal distributions that best fit the $S$ and $D$ data. Here, we tested the suitability of six probability distributions: normal, logistic, Weibull, gamma, 
lognormal and exponential. The choice of marginal distributions that best fit the data is based on the calculation of the Maximum Absolute Log-likelihood Value (MLV). Concerning each series of S and D, the MLV is calculated for the six distributions mentioned. The distribution showing the highest MLV is considered the most suitable for the series under consideration at the time.

\subsection{Return Period Estimation}

Drought return period analysis based on a single variable often leads to inaccurate results regarding event evolution. To model the drought return period more accurately, we performed our analysis based on bivariate joint distributions of duration and severity. The return period based on bivariate joint distributions can be defined as:

$$
T_{(D \geq d, S \geq s)}=\frac{E(L)}{P(D \geq d o r S \geq s)}=\frac{E(L)}{1-C\left[F_{D}(d), F_{S}(s)\right]}
$$

where $T_{(D \geq \text { dor } S \geq s)}$ is the return period when one or both thresholds are known. $E(L)$ is the expectation of the drought duration, which, in turn, is the sum of average $\mathrm{D}$ and $\mathrm{nD}$ (Figure 2).

\section{Results and Discussion}

\subsection{Drought Frequency}

Figure 3 shows the spatial distribution of mean and maximum drought severity over the NRB. The average drought severity across the NRB ranges from three to seven. The northern region has the highest values (Figure 3a). Conversely, on average, the lowest values are observed in the east-south portion of the NRB. However, when it comes to the maximum severity values observed in the analysis period, the east-south portion and the entire east coast region showed the most severe droughts (Figure $3 b$ ). Some points on the northern coast also exhibited extreme values relative to most of the NRB.

The northern NRB also stands out for its longer average drought duration, as D and S are positively correlated (Figure 4a). Further to the north of the NRB, average droughts of four and one half to seven months are noticed. The east-south portion of NRB, in turn, has the lowest D values, similar to the pattern observed for S (Figure 3a), with droughts lasting for two to three months. It is important to note that, although the two variables are highly correlated, the pattern will not necessarily be the same. Seen in northern NRB, a more uniform distribution of mean Severity is observed (Figure 3a), while mean Duration in the same sector exhibits a westward gradient (Figure 4a). Analyzing the maximum D observed throughout the NRB (Figure $4 b$ ), a pattern similar to maximum S (Figure 3b) is observed. The eastern region, which experienced the most severe droughts observed in the period under analysis, had the maximum Duration ever recorded, ranging from 14 to 24 months. The maximum Duration in the semiarid region varied from eight to 12 months.

The observed patterns are directly related to atmospheric phenomena that modulate climate variability in the NRB. The ITCZ is the main modulator of the rainy season in northern NRB $[15,69,70]$. During the austral summer, the ITCZ moves toward the southern hemisphere, due to the temperature gradient between the hemispheres, and reaches the northern portion of the NRB. A more southward displacement of the ITCZ causes increased precipitation, while a less southward migration of the same system causes a deficit of precipitation in the region. The main precipitation-generating phenomenon in the eastern portion of the NRB are the Easterly Wave Disturbances (EWD). This phenomenon consists of cloud bands that propagate westward in the trail of the trade winds and cause precipitation in the austral winter $[45,46,71,72]$. The frequency of this phenomenon determines the quality of the rainy season in the eastern sector. 

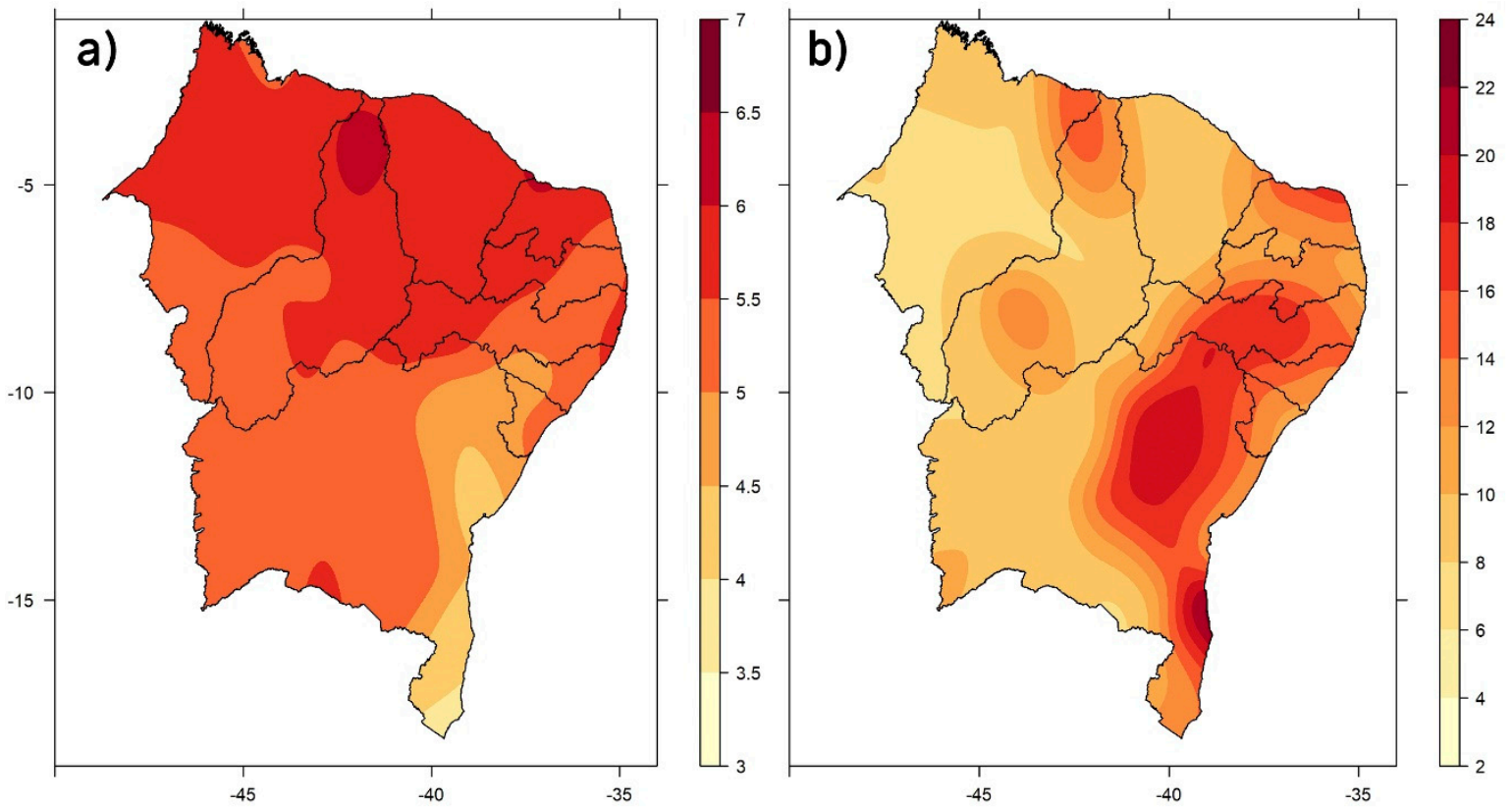

Figure 3. (a) Average and (b) Maximum severity (SPI) of drought in NRB during the period 1961-2017.
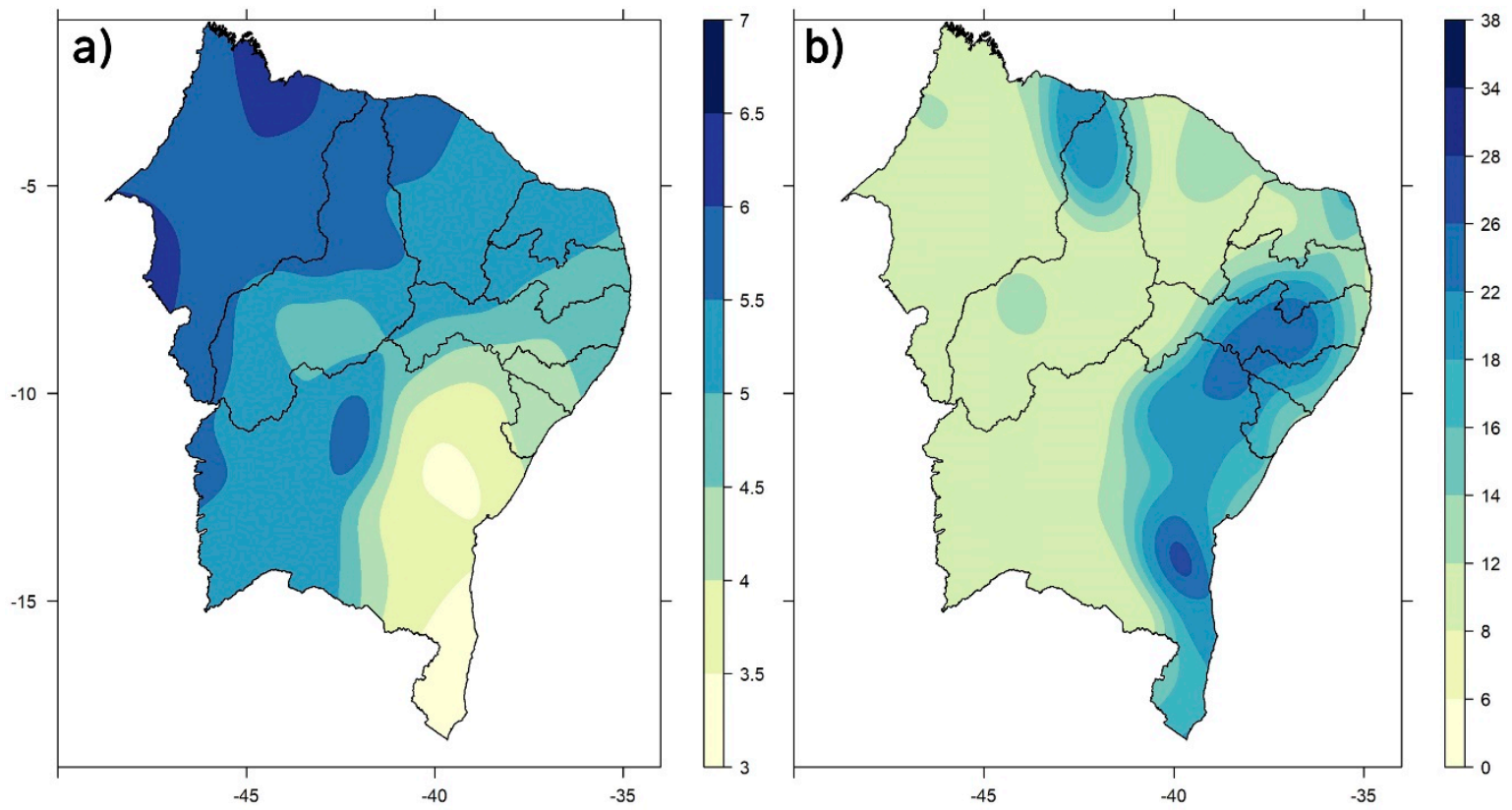

Figure 4. (a) Average and (b) Maximum duration (months) of drought in NRB during the period 1961-2017.

\subsection{Marginal Distributions}

The multivariate distributions obtained by copula are generated from the marginal distributions of the individual variables. The advantage of the copula method is the flexibility to consider the probabilistic nature of each variable individually. Therefore, the marginal distributions are the probability distributions that best fit the variables under analysis. We tested the following probability distributions: normal (Gaussian), lognormal, exponential, logistic, Weibull and gamma [73]. According to the criterion of lowest AIC, the distributions that best fit the data are illustrated in Figure 5. The distributions selected for the severity series were the normal, lognormal and exponential ones (Figure 5a). The spatial pattern presented is similar to that observed in the fields of mean $S$ and maximum S. Regarding the southeastern portion of the NRB, which had showed the lowest severity 
values (Figures 3a and 4a), the Gaussian distribution was the best match. Concerning most of the northern sector, where the highest severity values were observed, the variable was best modeled by exponential distributions. Conversely, the central and intermediate regions of the NRB were mostly better adjusted by lognormal distributions.

The time series of $\mathrm{D}$ showed spatial patterns (Figure $5 b$ ) that resemble the average and maximum D maps (Figure 4). Regarding the eastern portion, it was noted that the seasons with the longest drought durations were best modeled by the normal distribution.

Concerning the rest of the NRB, the duration of the drought was modeled by the exponential distribution.
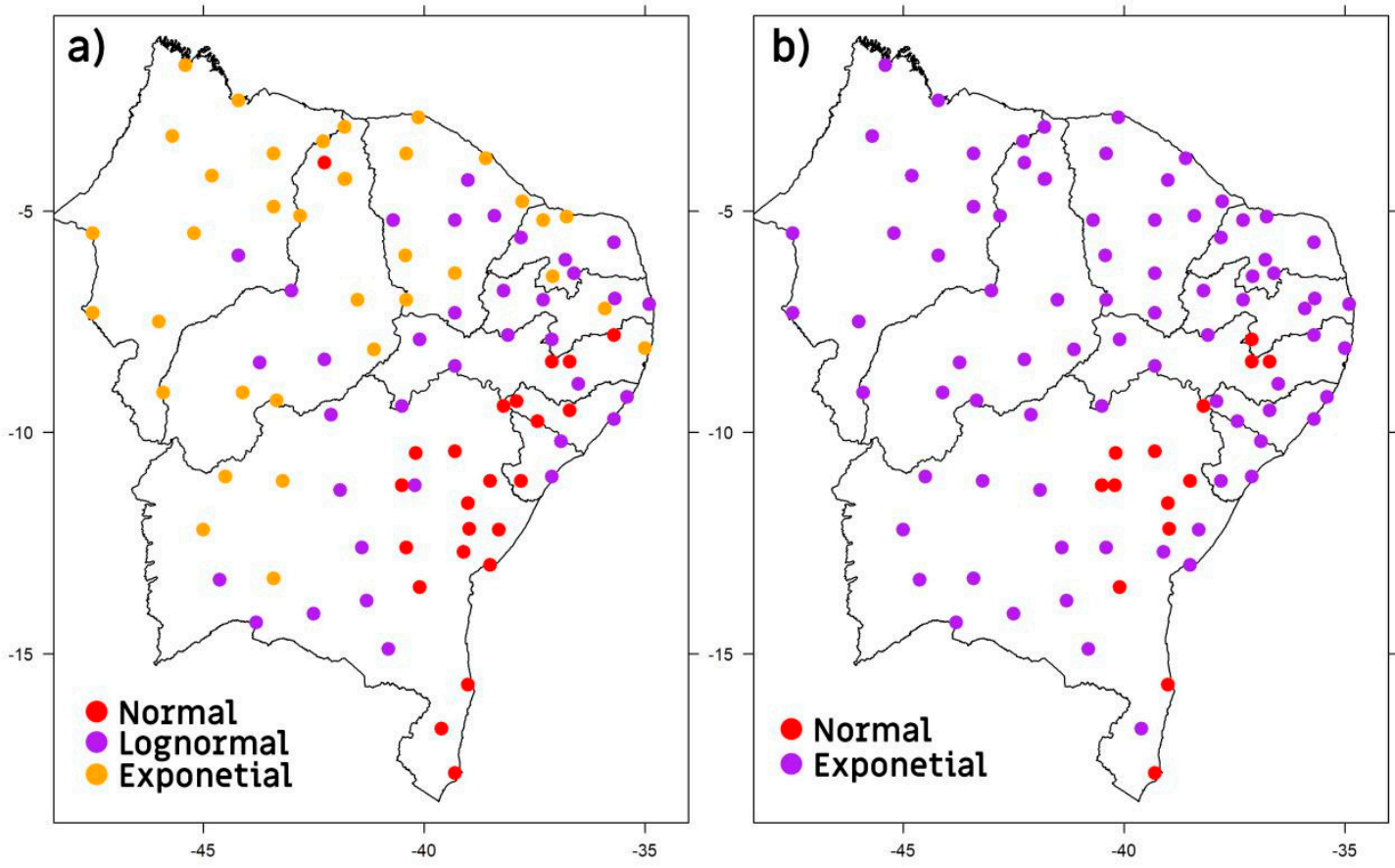

Figure 5. Probability distributions chosen according to the criterion of highest maximum log likelihood for series of drought (a) Severity and (b) Duration.

\subsection{Bivariate Joint Probability Distribution}

After obtaining the marginal distributions for each NRB point, it is possible to choose which copula best fits the series under analysis. The chosen copula should be able to model sets of relations of a linear and nonlinear nature between the Severity and Duration series. Figure 6 shows the best joint distribution functions for each surface weather station chosen according to the lowest AIC value criterion. Throughout the NRB, two joint distributions were chosen, the Clayton and Frank copulas. The southeastern portion of the NRB has a cluster of modeled stations by copula of the Clayton-type [74]. This region, according to previous maps, is characterized by less severe and longer lasting droughts (Figures 3 and 4). Conversely, the northeastern sector of the NRB, characterized by higher severity and duration values (Figures 3 and 4), exhibits a cluster of Frank-type copula-shaped stations. The western side of the NRB exhibits no significant pattern on any dominant copula.

\subsection{Return Period}

According to the selected joint distributions (Figure 6), it is possible to calculate the drought return period for a given level characterized by an $\mathrm{S}$ value (for Severity) and a D value (for Duration). Table 2 presents three drought classifications according to the definition of Wang et al, [33]. These classifications were used to illustrate the dynamics of the return period of the NRB seasons considering the hypothetical drought scenarios presented in Table 2. 


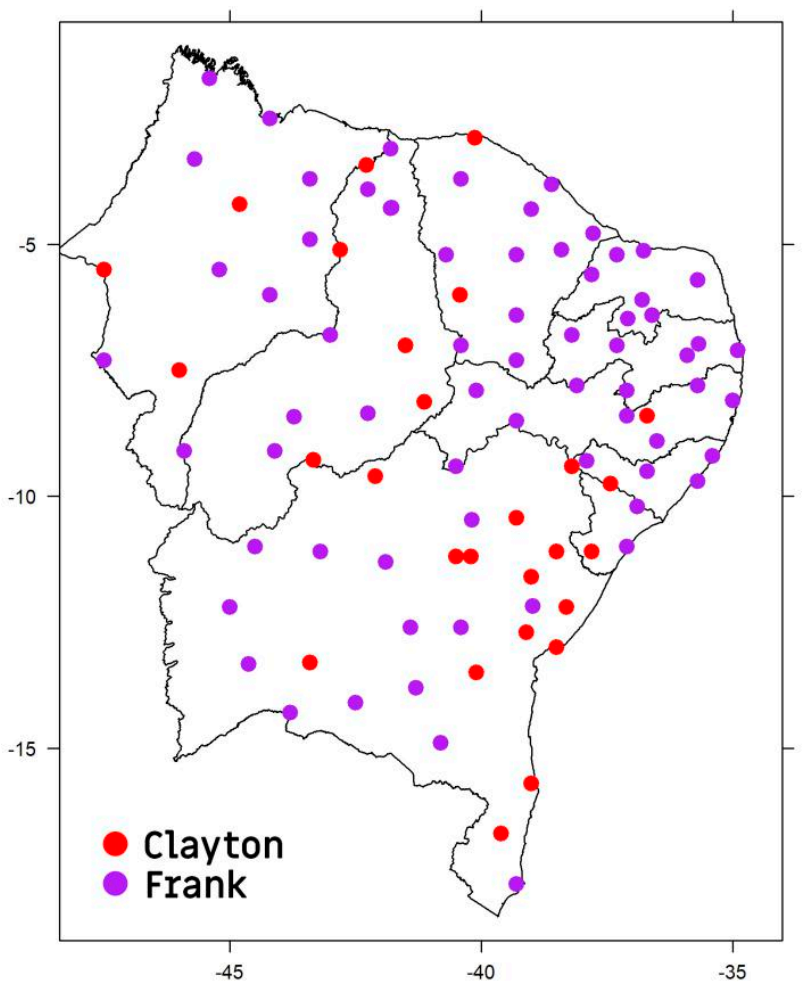

Figure 6. Copula classes chosen according to AIC criterion to extract joint distributions of Severity and Duration.

Applying the copula functions to the definitions of a weak drought $(S=3, D=3)$, it is observed that the return period is longer in the western side of the NRB (Figure 7a), with an average interval of 17 months between one drought and another. Therefore, weak droughts are more frequent on the eastern side, as they have a shorter return period ( 14 months). Regarding moderate droughts $(S=6$, $\mathrm{D}=6$ ), there is some homogeneity over the NRB domain (Figure $7 \mathrm{~b}$ ). The western sector continues to show the longest return period ( 26 months), but the difference is of only two months compared to the eastern sector ( 24 months). Concerning severe droughts $(S=9, D=9$; Figure $7 \mathrm{c})$, there is a clear inversion of the spatial pattern observed in previous maps. This time, the eastern portion has the longest return periods ( $\sim 60$ months) compared to the rest of the NRB domain ( 45 months). This indicates that severe droughts are more frequent in the semiarid region.

Table 2. Drought level parameters according to the criteria of Wang et al, [33].

\begin{tabular}{cc}
\hline Drought Level & Setting \\
\hline Weak drought & $S=3 \mathrm{D}=3$ \\
Moderate drought & $\mathrm{S}=6 \mathrm{D}=6$ \\
Strong drought & $\mathrm{S}=9 \mathrm{D}=9$ \\
\hline
\end{tabular}

The definitions of drought by [33] allow us to analyze drought dynamics from certain scenarios not necessarily representing actual values of droughts in the NRB. That is why we applied the average and maximum values of $S$ and $D$ obtained in the frequency analysis. This allowed us to obtain the empirical return period of the average droughts of each season and the return period of the most severe drought ever recorded in the time span comprised by the precipitation series. 

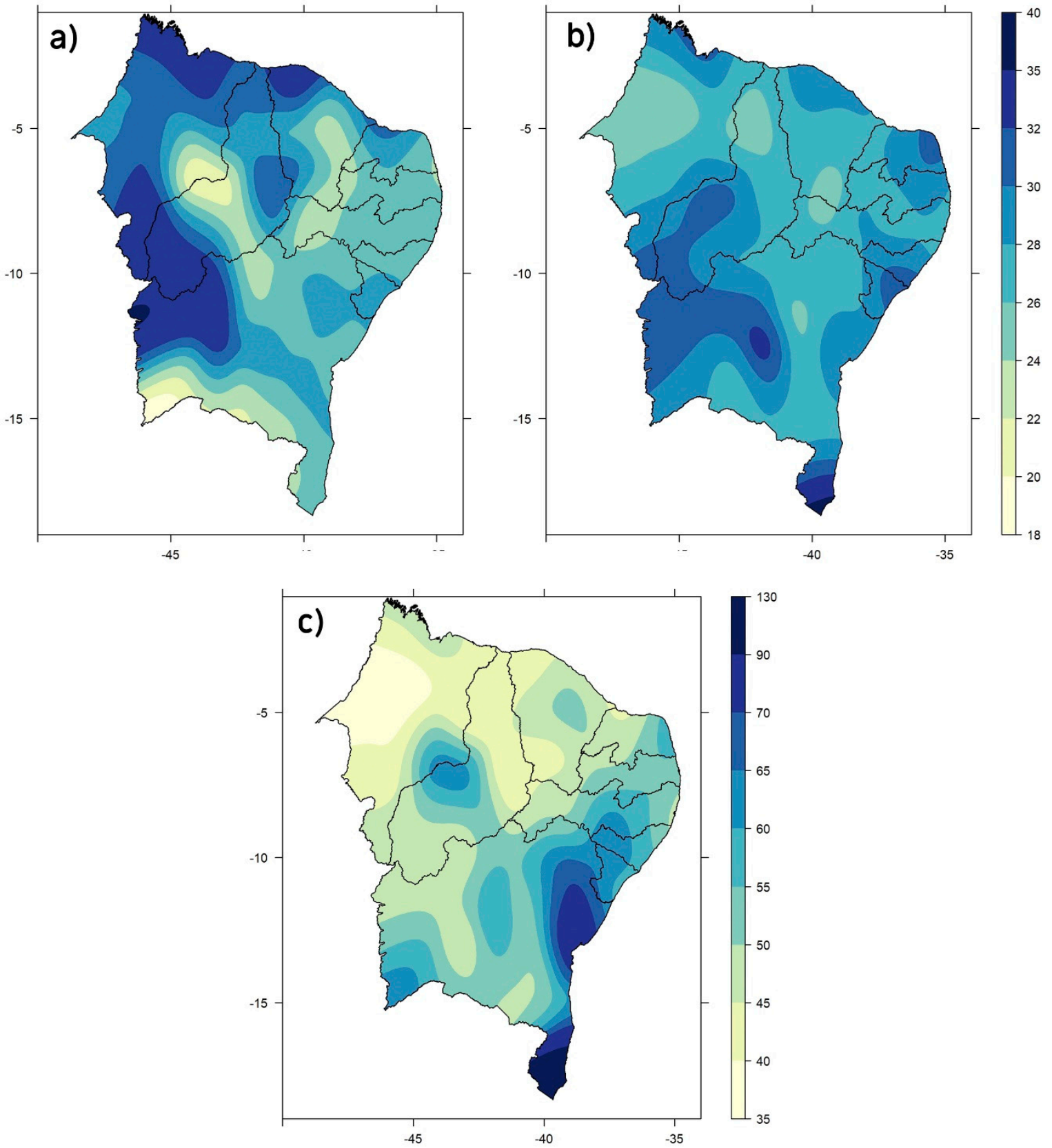

Figure 7. Return period (months) for (a) weak drought, (b) moderate drought and (c) strong drought.

Regarding the average droughts observed in the NRB, the western portion showed the longest return period of approximately 26 months (Figure 8a), with peaks above 28 months spread over that region and in the north of the NRB. Some areas located in the center and southeast of the NRB exhibited minimum return periods, of about 20 months, whereas some locations of the states of AL, SE, RN, $\mathrm{PB}, \mathrm{CE}$ and MA had similar return periods to that observed in the western sector. Regarding the most severe droughts (Figure 8b), the southern NRB stands out for its 90-150-month peaks. Added to the weather phenomena mentioned above that modulate climate variability in the eastern and northern NRB, there is also a significant role played by frontal systems on the coast of the state of Bahia [38]. The peak observed in that region indicates that the occurrence of droughts is related to less incursions of frontal systems and a lower performance of EWD. The northern portion of the NRB showed the shortest return periods ( $\sim 45$ months) and is, therefore, the region with the most frequent severe droughts. Concerning the southeastern and northeastern sectors, the return periods are around 55 months. 
According to Marengo et al, [1], there are widespread records of droughts in the NRB since the 15th century. The droughts that occurred within the period analyzed in this paper were as follows: 1966, 1970, 1976, 1979-1981, 1982-1983, 1986-1987, 1992-1993, 1997-1998, 2001-2002, 2005, 2010 and 2012-2016 Based on that record, the average return period between each event was 43 months, which is consistent with the numbers found in this study (Figure 7).

Part of such drought variability in the NRB is often associated with the occurrence of low frequency phenomena, such as the El Niño-Southern Oscillation (ENSO) [1,75]. During the occurrence of the ENSO positive/negative phase, there is a tendency for decreasing/increasing rainfall accumulations in the NRB. Another important low-frequency mode that modulates the NRB drought variability is the Tropical Atlantic Surface Temperature. The latitudinal annual migration of the ITCZ varies as a function of the surface temperature gradient between the Tropical North Atlantic and Tropical South Atlantic, referred to in literature as the Atlantic Dipole (AD) [17,76,77]. Namias et al, [15] further proposed that there are teleconnections between ENSO and AD that occur across the mid and high latitudes of the northern hemisphere through the North Atlantic Oscillation (NAO) patterns, as well as other modes of variability, such as the Pacific Decadal Oscillation (PDO) and the Atlantic Multidecadal Oscillation (AMO), described in detail by Kayano et al, [78,79].

Future scenario analysis for droughts in the NRB shows increased surface temperature and decreased precipitation [1]. The results of this study also imply an increase in the duration and frequency of droughts. Vieira et al, [80] pointed to an increase of approximately 5\% of areas susceptible to desertification in the NRB from 2000 to 2010. Franchito et al, [81] indicate a 20\% increase in aridity in the semiarid NRB region under climate change scenarios over the next 100 years. Significant positive drought trends during some NRB rainy seasons from 1980 to 2015 were shown by da Rocha Júnior et al, [35].

The NRB drought return period calculated for each season is useful information for planning long-term strategies to mitigate its effects $[33,66]$. The adjusted copula functions can be used operationally to monitor drought events, quantify their dangerousness during their evolution, and make it possible to adopt strategic actions in real time [82].
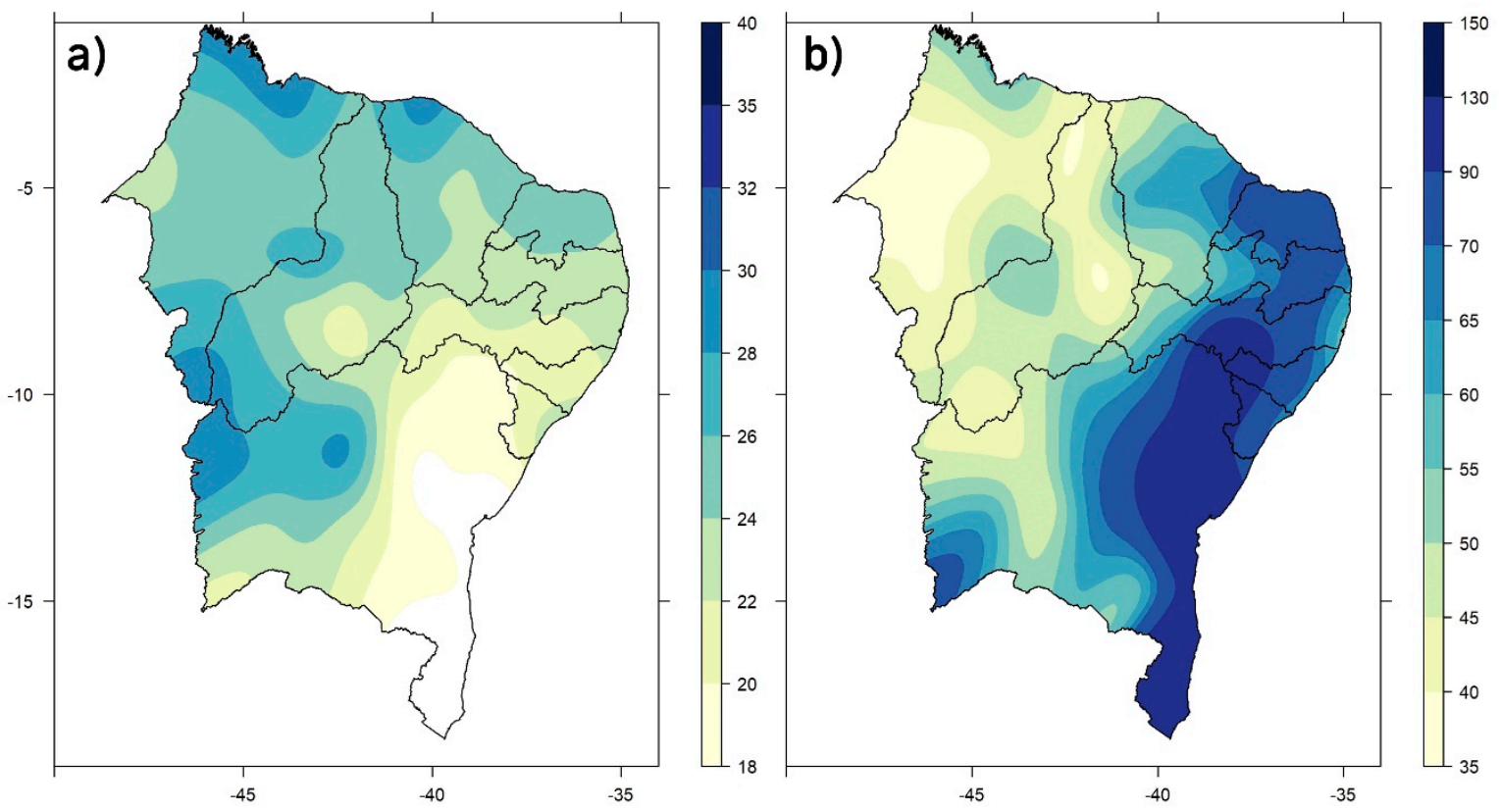

Figure 8. Return period (months) for (a) observed mean D and S values and (b) observed maximum D and S values for the period 1961-2017. 


\section{Conclusions}

The Brazilian Northeast is the most populous dry region in the world, with a marked climate variability that exposes the population to the risk of drought having strong environmental and social impacts. The need for drought studies using advanced research methods, especially in the context of climate change, is critical to improve crisis management demanded by long periods of drought.

The most severe and frequent droughts observed in the NRB, on average, are concentrated in the northern portion. Seen in this region, the observed duration ranged from three and a half to five and a half months. Conversely, the sector that experienced the most severe droughts observed during the period 1961-2017 was the eastern NRB. This area, which extends along the coast of six states from RN to BA, had droughts which lasted from 14 to 24 months.

The marginal distributions that best modeled the $S$ and $D$ series were exponential, normal, and lognormal. Regarding the $S$ series, it was observed that in the north there was the predominance of a better fit for exponential distributions, while in the central and eastern NRB, the lognormal and normal distributions were found to be better suited to deal with the data. Concerning the $\mathrm{D}$ series, a better performance of the lognormal distribution was noticed for nearly all of the NRB, except in the eastern sector where there was a higher frequency of normal distribution. Considering the choice of the marginal distributions of the D and S series for each season, the Frank and Clayton copula functions were chosen to model the drought return period in the NRB.

The analysis of scenarios with parameters of $S$ and $D$ given by [33] shows that, regarding mild droughts in the western portion of the NRB, they have longer return periods ( 17 months) relative to the eastern side ( 12 months). Regarding moderate droughts, there is a weak gradient pointing to the southwestern portion of the NRB. Moderate droughts throughout the NRB domain on average have a return period of around 22 months. Strong droughts, in their turn, presented opposite patterns to the ones found in weak droughts. The eastern side had a longer return period for severe droughts ( 55 months) compared to the western area ( $\sim 43$ months).

When analyzing the return period based on observed $S$ and $D$ values, it was noted that, for average values, the return period in the entire region is around 24 months. Still in this scenario of average $S$ and $D$, the southeast of the NRB stands out for presenting a return period of only about 20 months, whereas pockets above 28 months were found in the western and northern regions. Regarding maximum observed values of $\mathrm{D}$ and $\mathrm{S}$, the eastern portion stands out for having the longest return period (>60 months), especially in the southeastern region, where a return period above 90 months was observed. The northern NRB had the shortest return period ( 45 months), indicating that it is the NRB region with the highest frequency of severe droughts.

The results presented in this work are added to a hall of information useful to decision makers in terms of mitigating the negative effects of drought in the NRB. Moreover, they provide an initial methodological basis for an operational drought monitoring tool, contributing to real-time strategic decisions. Also, such knowledge can be applied in the quantification of the severity of future droughts from the representation of the hydrological cycle of models of the terrestrial system, as is the case of the Brazilian Earth System Model currently under development.

Author Contributions: Supervision, F.D.d.S.S.; Conceptualization, R.L.d.R.J. and F.D.d.S.S.; methodology, R.L.d.R.J.; F.D.d.S.S.; R.L.C.; H.B.G.; D.L.H. software, R.L.d.R.J. and F.D.d.S.S.; validation, R.L.d.R.J., R.L.C. and F.D.d.S.S.; formal analysis, R.L.d.R.J., R.L.C., H.B.G.; D.L.H.; D.D.C.P. and F.D.d.S.S.; data curation, R.L.d.R.J. and F.D.d.S.S.; writing-Original draft preparation, R.L.d.R.J. and F.D.d.S.S.; writing-Review and editing, R.L.d.R.J., R.L.C.; D.D.C.P. and F.D.d.S.S.; visualization, R.L.d.R.J., R.L.C.; D.D.C.P. and F.D.d.S.S.; funding acquisition, D.L.H. All authors have read and agreed to the published version of the manuscript.

Funding: This study was financed in part by the Coordenação de Aperfeiçoamento de Pessoal de Nível Superior-Brasil (CAPES)-Finance Code 001.

Acknowledgments: The authors would also like to thank CAPES for partially funding this work through the project CAPES/Modelagem\#88881.148662/2017-01, and INMET for the data.

Conflicts of Interest: The authors declare no conflicts of interest. 


\section{References}

1. Marengo, J.A.; Torres, R.R.; Alves, L.M. Drought in Northeast Brazil-past, present, and future. Theor. Appl. Climatol. 2016, 129, 1189-1200. [CrossRef]

2. Wilhite, D.A.; Glantz, M.H. Understanding the Drought Phenomenon: The Role of Definitions. Water Int. 1985, 10, 111-120. [CrossRef]

3. Cunha, A.P.M.A.; Alvalá, R.C.S.; Nobre, C.A.; Carvalho, M.A. Monitoring vegetative drought dynamics in the Brazilian semiarid Region. Agric. For. Meteorol. 2015, 214, 494-505. [CrossRef]

4. Cunha, A.P.M.A.; Tomasella, J.; Ribeiro-Neto, G.G.; Brown, M.; Garcia, S.R.; Brito, S.B.; Carvalho, M.A. Changes in the spatial-temporal patterns of droughts in the Brazilian Northeast. Atmos. Sci. Lett. 2018, 19, e855. [CrossRef]

5. Cunha, A.P.M.A.; Zeri, M.; Leal, K.D.; Costa, L.; Cuartas, L.A.; Marengo, J.A.; Tomasella, J.; Vieira, R.M.; Barbosa, A.A.; Cunningham, C.; et al. Extreme Drought Events over Brazil from 2011 to 2019. Atmosphere 2019, 10, 642. [CrossRef]

6. Alvala, R.C.S.; Cunha, A.P.M.A.; Brito, S.S.B.; Seluchi, M.E.; Marengo, J.A.; Moraes, O.L.L.; Carvalho, M.A. Drought monitoring in the Brazilian Semiarid region. An. Acad. Bras. Ciências 2017, 91,1-15. [CrossRef] [PubMed]

7. Martins, E.S.P.R.; Coelho, C.A.S.; Haarsma, R.; Otto, F.E.L.; King, A.D.; Van Oldenborgh, G.J.; Kew, S.; Philip, S.; Júnior, F.C.V.; Cullen, H. A multimethod attribution analysis of the prolonged northeast Brazil hydrometeorological drought (2012-16). Bull. Am. Meteorol. Soc. 2018, 99, 65-69. [CrossRef]

8. Martins, M.A.; Tomasella, J.; Rodriguez, D.A.; Alvalá, R.C.; Giarolla, A.; Garofolo, L.L.; Júnior, J.L.S.; Paolicchi, L.T.; Pinto, G.L. Improving droughtmanagement in the Brazilian semiarid through crop forecasting. Agric. Syst. 2018, 160, 21-30. [CrossRef]

9. Vincente-Serrano, S.M.; Beguería, S.; López-Moreno, J.I.; Angulo, M.; Kenawy, A.E. A new global 0.5 degrees gridded dataset (1901-2006) of a multiscalar drought index: Comparison with current drought index datasets based on the Palmer Drought Severity Index. J. Hydrometeorol. 2010, 11, 1033-1043. [CrossRef]

10. Finan, T.J.; Nelson, D. Making Rain, Making Roads, Making Do: Public and Private Adaptations to Drought in Ceará, Northeast Brazil. Clim. Res. 2001, 19, 97-108. [CrossRef]

11. Spinoni, J.; Antofie, T.; Barbosa, P.; Bihari, Z.; Lakatos, M.; Szalai, S.; Szentimrey, T.; Vogt, J. An overview of drought events in the Carpathian region in 1961-2010. Adv. Sci. Res 2013, 10, 21-32. [CrossRef]

12. Sinopse do Censo Demográfico 2010; Instituto Brasieliro de Geografia e Estatística-IBGE: Rio de Janeiro, Brazil, 2010. Available online: https://biblioteca.ibge.gov.br/index.php/biblioteca-catalogo?view=detalhes\&id= 249230 (accessed on 9 April 2020).

13. Eakin, H.C.; Lemos, M.C.; Nelson, D.R. Differentiating capacities as a means to sustainable climate change adaptation. Glob. Environ. Chang. 2014, 27, 1-8. [CrossRef]

14. Salvador, M.A.; de Brito, J.I.B. Trend of annual temperature and frequency of extreme events in the MATOPIBA region of Brazil. Theor. Appl. Climatol. 2018, 133, 253-261. [CrossRef]

15. Namias, J. Influence of northern hemisphere general circulation on drought in northeast Brazil. Tellus XXIV 1972, 4, 336-343.

16. Hastenrath, S.; Heller, L. Dynamics of climatic hazards in northeast Brazil. Q. J. R. Meteorol. Soc. 1977, 103, 77-92. [CrossRef]

17. Moura, A.D.; Shukla, J. On the dynamics of droughts in northeast Brazil: Observations, theory and numerical experiments with a general circulation model. J. Atmos. Sci. 1981, 38, 2653-2675. [CrossRef]

18. Hastenrath, S. Circulation and teleconnection mechanisms of Northeast Brazil droughts. Prog. Oceanogr. 2006, 70, 407-415. [CrossRef]

19. Kucharski, F.; Polzin, D.; Hastenrath, S. Teleconnection Mechanisms of Northeast Brazil Droughts: Modeling and Empirical Evidence. Rev. Bras. De Meteorol. 2008, 23, 115-125. [CrossRef]

20. Marengo, J.A.; Alves, L.M.; Soares, W.R.; Rodriguez, D.A.; Camargo, H.; Riveros, M.P.; Pabló, A.D. Two contrasting severe seasonal extremes in Tropical South America in 2012: Floods in Amazonia and Drought in Northeast Brazil. J. Clim. 2013, 26, 9137-9154. [CrossRef]

21. Lemos, M.C.; Finan, T.J.; Fox, R.W.; Nelson, D.R.; Tucker, J. The Use of Seasonal Climate Forecasting in Policymaking: Lessons from Northeast Brazil. Clim. Chang. 2002, 55, 479-507. [CrossRef] 
22. Nelson, D.R.; Finan, T.J. Praying for Drought: Persistent Vulnerability and the Politics of Patronage in Ceará, Northeast Brazil. Am. Anthropol. 2009, 111, 302-316. [CrossRef]

23. Costa, D.D.; Pereira, T.A.S.; Fragoso, C.R., Jr.; Madani, K.; Uvo, C.B. Understanding Drought Dynamics during Dry Season in Eastern Northeast Brazil. Front. Earth Sci. 2016, 4, 69. [CrossRef]

24. Brito, S.S.B.; Cunha, A.P.M.A.; Cunningham, C.C.; Alvalá, R.C.; Marengo, J.A.; Carvalho, M.A. Frequency, duration and severity of drought in the Semiarid Northeast Brazil region. Int. J. Climatol. 2017, 38, 517-529. [CrossRef]

25. Awange, J.; Mpelasoka, F.; Goncalves, R. When every drop counts: Analysis of droughts in Brazil for the 1901-2013 period. Sci. Total Environ. 2016, 566-567, 1472-1488. [CrossRef] [PubMed]

26. Cancelliere, A.; Salas, J.D. Drought probabilities and return period for annual streamflows series. J. Hydrol. 2010, 391, 77-89. [CrossRef]

27. Kim, T.; Valdes, J.B.; Yoo, C. Nonparametric approach for estimating return periods of droughts in arid regions. J. Hydrol. Eng. 2003, 8, 237-246. [CrossRef]

28. Hong, X.; Guo, S.; Xiong, L.; Liu, Z. Spatial and temporal analysis of drought using entropy-based standardized precipitation index: A case study in Poyang Lake basin, China. Theor. Appl Clim. 2015, 122, 543-556. [CrossRef]

29. Xu, X.; Xie, F.; Zhou, X. Research on spatial and temporal characteristics of drought based on GIS using remote sensing big data. Clust. Comput. 2016, 19, 757-767. [CrossRef]

30. Chebana, F.; Ouarda, T. Multivariate quantiles in hydrological frequency analysis. Environmetrics 2011, 22, 63-78. [CrossRef]

31. Xu, K.; Yang, D.; Xu, X.; Lei, H. Copula based drought frequency analysis considering the spatio-temporal variability in Southwest China. J. Hydrol. 2015, 527, 630-640. [CrossRef]

32. Ayantobo, O.O.; Li, Y.; Song, S.; Javed, T.; Yao, N. Probabilistic modelling of drought events in China via 2-dimensional joint copula. J. Hydrol. 2018, 559, 373-391. [CrossRef]

33. Wang, R.; Zhao, C.; Zhang, J.; Guo, E.; Li, D.; Alu, S.; Ha, S.; Dong, Z. Bivariate copula function-based spatial-temporal characteristics analysis of drought in Anhui Province, China. Meteorol. Atmos. Phys. 2018, 131, 1341-1355. [CrossRef]

34. Hui-Mean, F.; Yusof, F.; Yusop, Z.; Suhaila, J. Trivariate copula in drought analysis: A case study in peninsular Malaysia. Theor. Appl. Climatol. 2019, 138, 657-671. [CrossRef]

35. da Rocha Júnior, R.L.; dos Santos Silva, F.D.; Lisboa Costa, R.; Barros Gomes, H.; Herdies, D.L.; Rodrigues da Silva, V.P.; Candido Xavier, A. Analysis of the Space-Temporal Trends of Wet Conditions in the Different Rainy Seasons of Brazilian Northeast by Quantile Regression and Bootstrap Test. Geosciences 2019, 9, 457. [CrossRef]

36. Filho, T.K.; Assad, E.D.; Lima, P.R.S.R. Regiões pluviometricamente homogêneas no Brasil. Pesqui. Agropecu. Bras. 2005, 40, 311-322. [CrossRef]

37. Cavalcanti, I.F.A.; Ferreira, N.J.; Silva, M.G.A.J.; Dias, M.A.F.S. Tempo e Clima no Brasil; Oficina de Textos: São Paulo, Brazil, 2009.

38. Marengo, J.A.; Alves, L.M.; Alvala, R.C.C.; Cunha, A.P.M.A.; Brito, S.B.; Moraes, O.L.L. Climatic characteristics of the 2010-2016 drought in the semiarid Northeast Brazil region. An. Acad. Bras. Ciências 2018, 90, 1973-1985. [CrossRef]

39. Kousky, V.E. Frontal Influences on Northeast Brazil. Mon. Weather Rev. 1979, 107, 1140-1153. [CrossRef]

40. Kousky, V.E.; Gan, M.A. Upper tropospheric cyclonic vortices in the tropical South Atlantic. Tellus 1981, 33, 538-551. [CrossRef]

41. Costa, R.L.; De Souza, E.P.; Silva, F.D.D.S. Aplicação de uma teoria termodinâmica no estudo de um Vórtice Ciclônico de Altos Níveis sobre o nordeste do Brasil. Rev. Bras. Meteorol. 2014, 29, 96-104. [CrossRef]

42. Cordeiro, E.S.; Fedorova, N.; Levit, V. Synoptic and thermodynamic analysis of events with thunderstorms for alagoas state in a period of 15 years (1998-2012). Rev. Bras. Meteorol. 2018, 33, 685-694. [CrossRef]

43. De Carvalho, M.; Ângelo, V.; Oyama, M.D. Variabilidade da largura e intensidade da Zona de Convergência Intertropical atlântica: Aspectos observacionais. Rev. Bras. Meteorol. 2013, 28, 305-316. [CrossRef]

44. Silva, V.B.S.; Kousky, V.E.; Silva, F.D.S.; Salvador, M.A.; Aravequia, J.A. The 2012 severe drought over Northeast Brazil. Bull. Am. Meteorol. Soc. 2013, 94, 162.

45. Gomes, H.B.; Ambrizzi, T.; Herdies, D.L.; Hodges, K.; Da Silva, B.F.P. Rcio Easterly Wave Disturbances over Northeast Brazil: An Observational Analysis. Adv. Meteorol. 2015, 2015, 176238. [CrossRef] 
46. Gomes, H.B.; Ambrizzi, T.; Da Silva, B.F.P.; Hodges, K.; Dias, P.L.S.; Herdies, D.L.; Silva, M.C.L.; Gomes, H.B. Climatology of easterly wave disturbances over the tropical South Atlantic. Clim. Dyn. 2019, 53, 1393-1411. [CrossRef]

47. Aguilar, E.; Auer, I.; Brunet, M.; Peterson, T.C.; Wieringa, J. Guidelines on Climate Metadata and Homogenization; World Meteorological Organization: Geneva, Switzerland, 2003; p. 55.

48. Aguilar, E.; Peterson, T.C.; Ramírez Obando, P.; Frutos, R.; Retana, J.A.; Solera, M.; González Santos, I.; Araujo, R.M.; Rosa García, A.; Valle, V.E.; et al. Changes in precipitation and temperature extremes in Central America and northern South America, 1961-2003. J. Geophys. Res. 2005, 110, D23107. [CrossRef]

49. Aguilar, E.; AzizBarry, A.; Brunet, M.; Ekang, L.; Fernandes, A.; Massoukina, M.; Mbah, J.; Mhanda, A.; do Nascimento, D.J.; Peterson, T.C.; et al. Changes in temperature and precipitation extremes in western central Africa, Guinea Conakry, and Zimbabwe 1955-2006. J. Geophys. Res 2009, 114, D02115. [CrossRef]

50. Diniz, F.A.; Ramos, A.M.; Rebello, E.R.G. Brazilian climate normals for 1981-2010. Pesqui. Agropecu. Bras. 2018, 53, 131-143. [CrossRef]

51. Costa, R.L.; Baptista, G.M.M.; Gomes, H.B.; Silva, F.D.S.; da Rocha Júnior, R.L.; Salvador, M.A.; Herdies, D.L. Analysis of climate extremes indices over northeast Brazil from 1961 to 2014. Weather Clim. Extrem. 2020, 28, 100254. [CrossRef]

52. Palmer, W.C. Meteorological Drought; Research Paper No. 45. US Department of Commerce; Weather Bureau: Washington, DC, USA, 1965.

53. Allen, R.G.; Pereira, L.S.; Raes, D.; Smith, M. Crop Evapotranspiration: Guidelines for Computing Crop Water Requirements-FAO irrigation and Drainage Paper 56. Fao Rome 1998, 300, D05109.

54. Wells, N.; Goddard, S.; Hayes, M.J. A Self-Calibrating Palmer Drought Severity Index. J. Clim. 2004, 17, 2335-2351. [CrossRef]

55. Mckee, T.B.; Doesken, N.J.; Kleist, J. The Relationship of Drought Frequency and Duration to Time Scales. In Proceedings of the 8th Conference on Applied Climatology, Boston, MA, USA, 17-22 January 1993; Volume 17, pp. 179-183.

56. Livada, I.; Assimakopoulos, V.D. Spatial and temporal analysis of drought in greece using the Standardized Precipitation Index (SPI). Theor. Appl. Climatol. 2007, 89, 143-153. [CrossRef]

57. Mehr, A.D.; Sorman, A.U.; Kahya, E.; Afshar, M.H. Climate change impacts on meteorological drought using SPI and SPEI: Case study of Ankara, Turkey. Hydrol. Sci. J. 2020, 65, 254-268. [CrossRef]

58. Liu, D.; You, J.; Xie, Q.; Huang, Y.; Tong, H. Spatial and Temporal Characteristics of Drought and Flood in Quanzhou Based on Standardized Precipitation Index (SPI) in Recent 55 Years. J. Geosci. Environ. Prot. 2018, 6, 25-37. [CrossRef]

59. Standardized Precipitation Index User Guide. Available online: https://ibrary.wmo.int/index.php?lvl= notice_display\&id=13682\#.Xo7GuXERVPa (accessed on 9 April 2020).

60. Sun, Z.Y.; Zhang, J.Q.; Yan, D.H.; Wu, L.; Guo, E.L. The impact of irrigation water supply rate on agricultural drought disaster risk: A case about maize based on EPIC in Baicheng City, China. Nat. Hazard 2015, 78, 23-40. [CrossRef]

61. Sklar, A. Fonctions de repartition 'a n dimensions et leurs marges. Publ. De L'institut De Stat. De L'universit'e De Paris 1959, 8, 229-231.

62. Genest, C.; MacKay, J. The joy of copulas: Bivariate distributions with uniform marginal. Am. Stat. 1986, 40, 280-283.

63. Renard, B.; Lang, M. Use of a Gaussian copula for multivariate extreme value analysis: Some case studies in hydrology. Adv. Water Resour. 2007, 30, 897-912. [CrossRef]

64. Kao, S.-H.; Govindaraju, R.S. A copula-based joint deficit index for droughts. J. Hydrol. 2010, 380, 121-134. [CrossRef]

65. Chang, J.; Li, Y.; Wang, Y.; Yuan, M. Copula-based drought risk assessment combined with an integrated index in the Wei River Basin, China. J. Hydrol. 2016, 540, 824-834. [CrossRef]

66. Xiao, M.; Yu, Z.; Zhu, Y. Copula-based frequency analysis of drought with identified characteristics in space and time: A case study in Huai River basin, China. Theor. Appl. Climatol. 2019, 137, 2865-2875. [CrossRef]

67. Montaseri, M.; Amirataee, B.; Rezaie, H. New approuch in bivariate drought duration and severity analysis. J. Hidrol. 2018, 559, 166-181. [CrossRef]

68. Wilks, D.S. Statistical Methods in The Atmospheric Sciences, 3rd ed.; Academic Press: Cambridge, MA, USA, 2011. 
69. Molion, L.C.B.; Bernardo, S.O. Uma revisão dinâmica das chuvas no nordeste brasileiro. Rev. Bras. De Meteorol. 2002, 17, 1-10.

70. Lyra, M.J.A.; Cavalcante, L.C.V.; Levit, V.; Fedorova, N. Ligação Entre Extremidade Frontal e Zona de Convergência Intertropical Sobre a Região Nordeste do Brasil. Anuário Do Inst. De Geociências 2019, 42, 413-424. [CrossRef]

71. Yamazaki, Y.; Rao, V.B. Tropical cloudiness over the South Atlantic Ocean. J. Meteorol. Soc. Jpn. 1977, 55, 205-207. [CrossRef]

72. Torres, R.R.; Ferreira, N.J. Case Studies of Easterly Wave Disturbances over Northeast Brazil Using the Eta Model. Weather Forecast. 2011, 26, 225-235. [CrossRef]

73. Song, S.; Singh, V.P. Meta-elliptical copulas for drought frequency analysis of periodic hydrologic data. Stoch. Environ. Res. Risk Assess. 2010, 24, 425-444. [CrossRef]

74. Panagiotelis, A.; Czado, C.; Joe, H. Pair Copula Constructions for Multivariate Discrete Data. J. Am. Stat. Assoc. 2012, 107, 1063-1072. [CrossRef]

75. Magalhaes, A.R. The effects of climate variations on agriculture in Northeast Brazil. In The Impact of Climate Variations on Agriculture; Assessments in Semiarid Regions; Parry, M., Carter, T., Konijn, N., Eds.; Kluwer Academic Publishers: Amsterdam, The Netherlands, 1988; Volume 2, pp. 277-304.

76. Servain, J. Simple climatic indices for the tropical Atlantic Ocean and some applications. J. Geophys. Res. 1991, 96, 137-146. [CrossRef]

77. Servain, J.; Wainer, I.; Ayina, H.L.; Roquet, H. The Relationship Between the Simulated Climatic Variability Modes of the Tropical Atlantic. Int. J. Climatol. 2000, 20, 939-953. [CrossRef]

78. Kayano, M.T.; Andreoli, R.V. Decadal variability of northern northeast Brazil rainfall and its relation to tropical sea surface temperature and global sea level pressure anomalies. J. Geophys. Res. 2004, 109, C11. [CrossRef]

79. Kayano, M.T.; Capistrano, V.P. How the Atlantic Multidecadal Oscillation (AMO) modifies the ENSO influence on the South American rainfall. Int. J. Climatol. 2014, 34, 162-178. [CrossRef]

80. Vieira, R.M.S.P.; Tomasella, J.; Alvalá, R.C.S.; Sestini, M.F.; Affonso, A.G.; Rodriguez, D.A.; Barbosa, A.A.; Cunha, A.P.M.A.; Valles, G.F.; Crepani, E.; et al. Identifying areas susceptible to desertification in the Brazilian northeast. Solid Earth 2015, 6, 347-360. [CrossRef]

81. Franchito, S.H.; Reyes Fernandez, J.P.; Pareja, D. Surrogate Climate Change Scenario and Projections with a Regional Climate Model: Impact on the Aridity in South America. Am. J. Clim. Chang. 2014, 3, 474-489. [CrossRef]

82. De Michele, C.; Salvadori, G.; Vezzoli, R.; Pecora, S. Multivariate assessment of drought: Frequency analysis and dynamic return period. Water Resour. Res. 2013, 49, 6985-6994. [CrossRef] 